\section{Конституционно-судебная проверка соответствия международных и внутригосударственных договоров Конституции РФ}

\section{Осипян Б.A.*}

Деятельность Конституционного Суда РФ по проверке конституционности заключаемых Россией международных договоров имеет большое значение для оптимизации процесса выполнения российским государством своих международно-правовых обязательств и стабилизации международного и конституционного правопорядка ${ }^{1}$. Конституционно-судебная проверка внутригосударственной договорной практики также позволяет России укреплять конституционные основания ее дальнейшего государственно-правового, и в особенности федеративного, развития.

Пункты «В» и «Г» ч. 2 ст. 25 Конституции РФ и пункты «В» и «Г» ч. 1 ст. 3 Федерального конституционного закона «О Конституционном Суде Российской Федерации» от 211994 г. № 1-ФКЗ2 управомочивают Конституционный Суд РФ разрешать дела о соответствии Конституции РФ не вступивших в силу международных договоров Российской Федерации, а также договоров между органами государственной власти Российской Федерации и органами государственной власти ее субъектов, договоров между органами государственной власти субъектов России.

Часть 1 ст. 34 Федерального закона «О международных договорах Российской Федерации» от 15 июля 1995 г., ${ }^{3}$ устанавливая требования соответствия международных договоров России Конституции РФ, предоставляет Конституционному Суду РФ право при заключении

* Осипян Борис Арташесович - к.ю.н., доцент, специальный корреспондент журнала «Представительная власть - XXI век» Комитетов Государственной Думы Федерального Собрания РФ, член Союза Журналистов России и Международной Федерации Журналистов.

${ }^{1}$ См.: Осипян Б.А. Конституционные гарантии международной безопасности // Конституционное и муниципальное право. МГУ. 2005. № 5.

${ }^{2}$ Собрание законодательства РФ.1994. № 13. Ст. 1447.

${ }^{3}$ Собрание законодательства РФ. 1995. № 29. Ст. 2757. международных договоров разрешать возможные споры о компетенции между федеральными органами государственной власти, а также между органами государственной власти Российской Федерации и органами государственной власти ее субъектов. В тех случаях, когда заключение Россией международного договора затрагивает полномочия ее субъектов, проводится процедура согласования проекта заключаемого международного договора между федерацией и ее субъектами. Порядок и сроки проведения такого согласования и координации совместных действий по заключению международного договора устанавливаются ст. 4 указанного Федерального закона.

Согласно статьям 24 и 34 Федерального закона от 15 июля 1995 г. «О международных договорах Российской Федерации» международные договоры вступают в силу после принятия Государственной Думой РФ специального закона о ратификации данного международного договора и последующего одобрения его Советом Федерации РФ. Законопроект вместе с официальным текстом международного договора вносится в Государственную Думу Президентом РФ или Правительством РФ в форме предложения о ратификации указанного международного договора. Предложение (при необходимости также соответствующее заключение Правительства РФ согласно ст. 104 Конституции РФ) должно быть обосновано фактом соответствия международного договора положениям Конституции РФ и действующего законодательства, финансово-экономическим расчетом и возможными целесообразными последствиями.

Правом обращения в Конституционный Суд РФ с запросом о проверке конституционности не вступившего в силу международного договора Российской Федерации обладают Президент РФ, одна пятая часть Палат Федерального Собрания РФ, Правительство РФ, Верховный Суд РФ, Высший Арбитражный Суд РФ, органы законодательной и исполнительной власти субъектов Российской Федерации. Запрос допустим только в случае сомнения заявителя по поводу соответствия Конституции РФ подлежащего ратификации или утверждению конкретного международного договора. Такой порядок закреплен ст. 88 Федерального конституционного закона «О Конституционном Суде Российской Федерации» от 21 июля 1994 г. №1-ФКЗ.

Как видим, Конституционный Суд РФ, как отдельная ветвь высшей государственной власти, не может по своей инициативе поставить вопрос о конституционности не вступившего в силу международного 
договора. Представляется, что устранение Конституционного Суда РФ от инициативного участия в решении столь серьезных вопросов является очевидным неправомерным пробелом в действующем российском законодательстве. Поэтому для своевременного и действенного судебно-конституционного контроля над международными договорами и соглашениями Конституционный Суд РФ, как самостоятельная и ответственная ветвь высшей государственной власти, должен быть правомочным при необходимости проявлять собственную инициативу в деле проверки конституционности международных договоров и соглашений.

В соответствии со ст. 89 Федерального конституционного закона «О Конституционном Суде РФ» запрос о проверке конституционности не вступившего в силу международного договора Российской Федерации допустим, когда заявитель сомневается в его конституционности и считает его не подлежащим ратификации и введению в действие на территории России. Запрос о конституционности не вступившего в силу международного договора не допускается, если заявитель не дает надлежащего обоснования его неконституционности и если международный договор не подлежит ратификации со стороны Государственной Думы РФ или утверждению иным федеральным органом государственной власти. Если Конституционный Суд РФ после рассмотрения запроса находит положения международного договора не соответствующими Конституции РФ, то он в соответствии со ст. 91 Федерального конституционного закона «О Конституционном Суде РФ» выносит постановление о неправомерности введения в действие и применения неконституционного международного договора, о невозможности его ратификации и утверждения Российской Федерацией. Такой порядок установлен п. 6 ст. 125 Конституции РФ и ч. 2 ст. 79 Федерального конституционного закона «О Конституционном Суде Российской Федерации», которые гласят, что не вступившие в силу международные договоры Российской Федерации, признанные не соответствующими Конституции РФ, не подлежат введению в действие и применению. В этих случаях не требуется издания какого-либо нового нормативно-правового акта об отмене введения в действие неконституционного международного договора или соглашения.

Как известно, ст. 3 действующего Федерального конституционного закона «О Конституционном Суде Российской Федерации» позволяет Конституционному Суду РФ осуществлять только предварительный конституционный контроль над не вступившими в силу международными договорами и соглашениями. Нам такое ограничение кажется не совсем правомерным и целесообразным. Для решения подобных казусов Конституционный Суд РФ должен получить дополнительную возможность для контроля конституционности также вступивших в силу международных договоров и соглашений.й суд РФ должен получить дополнительную возможность для контроля конституционности также вступивших в силу Конституционный Суд РФ должен иметь также возможность для последующего контроля конституционности хода выполнения вступившего в силу международного договора Российской Федерации и для проверки конституционности практики договорного процесса на международном уровне. Следовательно, в пункт «г» ч. 1 ст. 3 Федерального конституционного закона «О Конституционном Суде Российской Федерации» необходимо внести поправку-дополнение о полномочии Конституционного Суда РФ проверять конституционность практики выполнения заключенных международных договоров Российской Федерации. Иными словами, заключение Конституционного Суда РФ о конституционности практики заключения, выполнения, изменения и прекращения международного договора должно быть обязательным. Если заключение Конституционного Суда РФ отрицательное, то согласно ч. 6 ст. 125 Конституции РФ международные договоры и соглашения, не соответствующие Конституции РФ не подлежат введению в действие и применению, а действующие международные договоры должны быть надлежащим образом изменены или прекращены.

Конституционный Суд РФ также должен иметь возможность для предостережения руководства страны от заключения подобного рода международных договоров и соглашений путем инициативного предложения соответствующих поправок в систему действующего конституционного законодательства. Более того, Конституционный Суд РФ должен иметь также возможность как для абстрактного, так и для конкретного способа контроля над правомерностью и конституционностью положений заключаемых и уже заключенных международноправовых соглашений. Дело в том, что наличные погрешности, обнаруженные в международно-правовых соглашениях и процессах их выполнения или прекращения, должны быть исправлены не только тогда, когда «грянет гром», а в момент, когда это стало известно находившемуся в правовом заблуждении государству. Разумеется, между- 
народно-правовые договоры и соглашения должны быть выполнены согласно традиционному принципу добросовестного выполнения договоров - pacta sunt servanda. Тем не менее даже международно-правовые контрагенты России должны знать о неправомерном и невыгодном для России характере заключенного договора, чтобы в следующий раз не соблазниться и воздержаться от изначально неправомерных и неконституционных предложений Российской Федерации.

Высокая правосознательная и мудрая позиция Конституционного Суда РФ в процессе предварительного и последующего контроля над правомерностью и конституционностью заключенных и заключаемых международно-правовых договоров и соглашений должна способствовать защите правомерных интересов России с целью сохранения ее национального достоинства и укрепления ее международного авторитета. Произвольный отказ от такой потенциальной возможности Конституционного Суда РФ в деле укрепления правовых основ российского государства в международных сношениях является не чем иным, как отказом в признании за третьей - судебной - высшей ветвью единой государственной власти права представлять Россию в триедином облике, т.е. в ее конституционно-судебной ипостаси.

Примечательно то, что п. 2 ст. 99 Основного закона ФРГ предусматривает следующее правило: «Если в юридическом споре возникает сомнение, является ли норма международного права составной частью федерального права согласно ст. 25 настоящего закона, суд должен получить решение Федерального конституционного суда» ${ }^{4}$. Конституционный Суд РФ должен иметь правомочие осуществлять предварительный и последующий контроль и проверку конституционности заключенных и заключаемых международных договоров Российской Федерации, поскольку Конституция РФ содержит в себе ряд принципов, на которых должна основываться внешняя, в том числе международно-договорная, политика российского государства ${ }^{5}$.

Представляется, что любое уважающее себя суверенное государство имеет право признать или не признать те или иные принципы и положения международного права в качестве общепризнанных и обязательных на основании понятия «правомерность», равно как и выбрать оптимальные способы для их применения на своей территории.

${ }^{4}$ См.: Конституции зарубежных стран. Сборник. М., 2003. С. 161.

${ }^{5}$ См. более подробно: Осипян Б.А. Конституционные гарантии международной безопасности // Конституционное и муниципальное право. 2005. № 5.
Как отмечает Г.М. Даниленко, Конституционный Суд РФ на основании ст. 125 Конституции РФ не учитывает приоритет международноправовых документов в своей правоприменительной практике ${ }^{6}$ Хотя Конституционный Суд РФ в своей деятельности использует правовые позиции Европейского Суда по правам человека, он, тем не менее, может и должен иметь возможность собственного усмотрения при решении подобных дел на территории Российской Федерации. Выражаясь словами В.А. Туманова, прецеденты «Страсбургского Суда» не носят обязательного характера для законодателя и судебной системы государства - члена Европейской Конвенции, которую ратифицировала Россия?.

По замечанию Н.В. Витрука ${ }^{8}$, в практике Конституционного Суда РФ за более чем десятилетний период его деятельности не было ни одного случая рассмотрения вопроса о конституционности международного договора, не вступившего в силу, хотя положения Конституции РФ имеют приоритет над положениями международных договоров. Поэтому необходимо законодательно установить систему правил о порядке обязательной проверки конституционности международных договоров до вступления их в силу на территории Российской Федерации. Ведь, осуществляя конституционно-судебный контроль над соответствием не вступивших в силу международных договоров России положениям Конституции РФ, Конституционный Суд РФ обязан также поддержать процесс конституционного признания и беспрепятственной реализации основных прав и свобод человека в правовом пространстве Россиия.

Положения международно-правовых договоров, заключенных Россией с другими государствами, необходимо признать в качестве возможных источников конституционного права. Этому может способствовать процесс скорейшей трансформации общепризнанных норм международных договоров в конституционное законодательство России в соответствии со статьей 15 Конституции Р $\Phi^{10}$. Однако, как верно ${ }^{6}$ См.: Даниленко Г.М. Применение международного права во внутренней правовой системе России: практика Конституционного Суда РФ // Государство и право. 1995. № 11. С. 116.

${ }^{7}$ См.: Туманов В.А. Европейский суд по правам человека. Очерк организации и деятельности. М., 2001. С. 48.

${ }^{8}$ Витрук Н.В. Конституционное правосудие. М., 2005. С. 443.

${ }^{9}$ См.: Морщакова Т.Г. Применение международно-правовых норм о правах человека в конституционном правосудии // Конституционное правосудие на рубеже веков. М., 2002. C. 183.

${ }^{10}$ См.: Лукашук И.И. Конституционное право и международное право // Московский журнал международного права. 1995. 
замечает С.А. Авакьян, роль Конституционного Суда РФ в этих процессах заключается в том, чтобы не допускать произвольной интервенции в российскую правовую систему изначально неправомерных конституционно-законодательных положений; машинально не признавать ценности каких-то членов международного сообщества как имеющих приоритет над системой конституционных ценностей, принципов, институтов и функций, чтобы, наконец, прямо или косвенно не ущемить и тем более не утратить национальный государственный суверенитет России ${ }^{11}$. Таким образом, признанные Российской Федерацией положения международного права должны являться источниками конституционного права в той мере, в какой они совершенствуют и делают более правомерной и действующей Конституцию России.

Объектом конституционного контроля и проверки являются не только международные договоры Российской Федерации, но также внутригосударственные, или внутрироссийские, договоры и соглашения. На основании ст. 84 Федерального конституционного закона «О Конституционном Суде Российской Федерации» от 21 июля 1994 г. № 1-ФКЗ правом обращения в Конституционный Суд РФ с запросом о конституционности предусмотренных п. «в» ч. 2 ст. 125 Конституции РФ договоров между органами государственной власти Российской Федерации обладают Президент РФ, палаты Федерального Собрания РФ, Правительство РФ, Верховный Суд РФ, Высший Арбитражный Суд РФ, органы законодательной и исполнительной власти субъектов Российской Федерации. Однако Конституционный Суд РФ вправе рассмотреть не всякий запрос указанных субъектов конституционного права. К примеру, согласно ст. 85 Федерального конституционного закона «О Конституционном Суде Российской Федерации» такой запрос недопустим, если требуется проверка конституционности нормативного акта субъекта Российской Федерации по вопросам его исключительного ведения.

В соответствии с ч. 3 ст. 11 Конституции РФ разграничение предметов ведения и полномочий между органами государственной власти Российской Федерации и органами государственной власти ее субъектов осуществляется настоящей Конституцией, Федеративным и иными договорами о разграничении предметов ведения и полномочий. Федеральные органы исполнительной власти и органы исполнительной власти субъектов Российской Федерации вправе передавать друг

${ }^{11}$ Авакьян С.А. Конституционное право России. В двух томах. Т. 1. М., 2005. С. 74. другу свои полномочия, если это не противоречит положениям Конституции РФ и федерального законодательства.

В Федеральном законе «О принципах и порядке разграничения предметов ведения и полномочий между органами государственной власти Российской Федерации и органами государственной власти субъектов Российской Федерации» ${ }^{12}$ под понятием договора понимается форма добровольного двух- и более стороннего (между органами государственной власти Федерации и ее субъектами) согласования взаимных обязанностей и способов их исполнения. Содержание такого договора не должно противоречить положениям Конституции РФ и действующего федерального законодательства ${ }^{13}$. Обязанностью Конституционного Суда РФ является постоянная проверка и контролирование правомерности и конституционности внутригосударственных договоров, а также процедуры их подписания. Для упорядочения договорного процесса Указом Президента РФ от 20 июля 1994 г. № 1499 (утратил силу) $)^{14}$ сначала было утверждено Положение о Комиссии при Президенте РФ по подготовке договоров о разграничении предметов ведения и полномочий между федеральными органами государственной власти Российской Федерации и органами государственной власти субъектов Российской Федерации. Однако сам порядок подготовки и подписания договоров и соглашений был установлен лишь 12 марта 1996 г. Указом Президента РФ № 370. Этим Указом было утверждено Положение о порядке работы по разграничению предметов ведения и полномочий между федеральными органами государственной власти Российской Федерации и органами государственной власти субъектов Российской Федерации ${ }^{15}$.

Согласно п. 5 Положения от 12 марта 1996 г. проекты договоров между федеральными органами государственной власти Российской Федерации и органами государственной власти субъектов Российской Федерации и приложенных к ним соглашений вносятся в Комиссию высшим должностным лицом субъекта РФ или его уполномоченным. Затем в десятидневный срок федеральные органы исполнительной власти представляют в Комиссию свои замечания по представленным проектам. После этого проекты договоров, соглашений и заключений ${ }^{12}$ Российская газета. 30 июня 1999 г.

${ }^{13}$ См.: Лексин И.В. Договорное регулирование федеративных отношений в России. M., 1998.

${ }^{14}$ Собрание законодательства РФ.1994. № 13. Ст. 1475.

${ }^{15}$ Собрание законодательства РФ. 1996. № 12. Ст. 1058. 
направляются Президенту РФ и Председателю Правительства РФ, и, наконец, происходит процедура их подписания главами (уполномоченными) субъектов РФ. Конституционный Суд РФ обязан тщательно проверять конституционность и законность процедуры подписания таких договоров и соглашений.

Еще лет шесть-семь назад договоры и соглашения между органами государственной власти Российской Федерации и ее субъектов были основным методом упорядочения федеративных отношений. Согласно данным правовой статистики, общее количество таких договоров превысило полсотни, а количество производных от них соглашений достигло более трех сотен ${ }^{16}$. Несмотря на многолетнюю практику договорного строительства федеративных отношений, в начале девяностых годов прошлого века законодательно не был установлен порядок заключения договоров и соглашений, механизмы ответственности за их ненадлежащее исполнение и т.д. ${ }^{17}$. Такая неопределенность со временем привела к необходимости конституционного и законодательного определения таких понятий, как разграничение предметов ведения и полномочий, совместные полномочия, их делегирование и т.д. Все эти понятия и определения были закреплены уже в статьях $5,11,71$, 72 и 78 Конституции РФ. Отныне разграничение предметов ведения и полномочий между Российской Федерацией и ее субъектами должно было производиться прежде всего на основании Конституции РФ и не противоречащих ей внутрифедеральных договоров. Поэтому доконституционная спорадическая практика заключения договоров между субъектами федерации закономерно привела к тому, что заключенные договоры в основном противоречили положениям Конституции РФ и федерального законодательства. В начале 2000 г. на смену договорному процессу развития федеративных отношений постепенно пришла тактика фактической централизации федеральной власти (тактика укрепления «вертикали власти») при сохранении формальных атрибутов идеи федерализма. Эта тенденция не могла не повлиять и на деятельность Конституционного Суда РФ в сфере проверки конституционности внутрифедеральных договоров и соглашений. Разумеется, Конституционный Суд РФ играет весьма важную роль в деле устранения правовых (в том числе конституционных) погрешностей и недо-

${ }^{16}$ См.: Глигич-Золотарева М.В. Правовые основы федерализма. М., 2006. С. 277.

${ }^{17}$ См.: Овсепян Ж.И. Двусторонние договоры РФ и республик в ее составе // СевероКавказский юридический вестник. 1999. № 4. четов в сфере регулирования федеративных отношений, однако его решения иногда страдают размытостью (выходом за пределы компетенции) и непоследовательностью и потому не всегда эффективны для перспективного развития федеративных отношений.

Роль договоров между субъектами Российской Федерации возрастает особенно там, где Конституция РФ и федеральное законодательство содержат ссылки на соответствующие договоры. Так, например, согласно ч. 4 ст. 66 и ст. 73 Конституции РФ отношения автономных округов, входящих в состав края или области, регулируются также договором между органами государственной власти перечисленных субъектов Российской Федерации, которые вне пределов ведения Российской Федерации и вне предметов совместного ведения обладают всей полнотой государственной власти. Если положения Конституции РФ и федерального законодательства не устанавливают порядка регулирования тех или иных правоотношений между равноправными субъектами Российской Федерации и договора между ними нет, то Конституционный Суд РФ должен воздерживаться от соблазна самовольно сочинять конституционные или законодательные нормы. В одном из своих решений Конституционный Суд РФ все же не смог удержаться от такого соблазна и вышел далеко за пределы своей компетенции. Например, в постановлении от 14 июля 1997 г. № 12-П ${ }^{18}$ по делу о толковании содержащегося в ч. 4 ст. 66 Конституции РФ положения о вхождении автономного округа в состав края, области Конституционный Суд РФ неправомерно и необоснованно предположил, что отсутствие договора между такими равноправными субъектами Российской Федерации, как автономный округ и край (область), не может служить препятствием для распространения юрисдикции органов государственной власти края, области на автономный округ. Таким образом, Конституционный Суд РФ, ссылаясь на п. 3 ст. 26 Федерального закона «Об общих принципах организации законодательных (представительных) и исполнительных органов государственной власти субъектов Российской Федерации» от 6 октября 1999 г. № 184-Ф3 ${ }^{19}$, занял такую правовую позицию, которой фактически отказал автономным округам как равноправным субъектам Российской Федерации в их праве по своему усмотрению распоряжаться тем объемом полно-

${ }^{18}$ Собрание законодательства РФ.1997. № 29.Ст. 3581.

${ }^{19}$ См.: Конституция Российской Федерации. Постатейные материалы. М., 2005. С. $435-$ 492. 
мочий, которые предоставлены им ст. 72 Конституции РФ. По справедливому замечанию М.В. Глигич-Золотаревой, из пятидесяти полномочий автономным округам достались лишь восемнадцать, а остальные полномочия произвольно были изъяты из их ведения и переданы краям и областям ${ }^{20}$. Подобная непоследовательность правовых позиций и решений Конституционного Суда РФ проявилась также в постановлении Конституционного Суда РФ от 31 июля 1995 г. при рассмотрении «чеченского дела», в котором количество особых мнений судей достигло беспрецедентного максимума ${ }^{21}$.

При заключении договоров и соглашений между федеральными органами государственной власти Российской Федерацией и ее субъектами должен соблюдаться конституционно закрепленный принцип федерализма ${ }^{22}$. Это предполагает, что при проверке конституционности положений таких договоров и соглашений между договаривающимися сторонами Конституционный Суд РФ должен всегда учитывать конституционные цели и требования ст. 5 Конституции РФ о праве народов на самоопределение ${ }^{23}$. Иными словами, и Федеральное Собрание, и Конституционный Суд РФ обязаны предусмотреть необходимость и реальную возможность культурного развития национальных субъектов Российской Федерации, а также запретить возможность произвольных изменений статуса субъектов России и перераспределений полномочий посредством административно-правовых методов. Соблюдение баланса правомерных интересов федеральных и региональных органов государственной власти должно стать одним из основных ориентиров в деятельности Конституционного Суда РФ. Более взвешенный подход к решению конфликтов между центром и регионами России отражен в постановлениях Конституционного Суда РФ от 14 июля 1997 г. и от 16 ноября 2004 г. по делу о проверке конституционности положений п. 2 ст. 10 Закона Республики Татарстан «О языках народов Республики Татарстан» ${ }^{24}$.

По мнению некоторых ученых ${ }^{25}$, конституционная база в России недостаточна для обеспечения эффективности договорного процесса,

${ }^{20}$ См.: Глигич-Золотарева М.В. Правовые основы федерализма. М., 2006. С. 293, 301. ${ }^{21}$ См.: Собрание законодательства РФ. 1995. № 33. Ст. 3424.

${ }^{22}$ CM.: Elazar D. Federalism and the Way to Peace. Institute of Intergovernmental Relations. Queens University, Kingston, Ontario (Canada), 1994.

${ }^{23}$ Cм.: Hannum H. Autonomy, Sovereignty and self-Determination. Philadelphia, 1990.

${ }^{24}$ См.: Собрание законодательства РФ. 1997. № 19. Ст. 3581; 2004. №47. Ст. 4691.

${ }^{25}$ См.: Глигич-Золотарева М.В. Правовые основы федерализма. М., 2006. С. 219. поскольку сама Конституция РФ не предусматривает возможности перераспределения полномочий субъектов России в рамках статей 71 и 72 Конституции РФ. Например, правовые позиции Конституционного Суда РФ, выраженные в постановлении от 9 января 1998 г. № 1-П ${ }^{26}$ по делу о конституционности Лесного кодекса, нисколько не снимают актуальности уточнения полномочий в рамках совместного ведения путем заключения двусторонних договоров ${ }^{27}$. Представляется, что договорный метод урегулирования федеративных правоотношений между федеральными и региональными органами исполнительной власти на твердом фундаменте Конституции РФ еще полностью себя не исчерпал. Следовательно, в действующее законодательство и впоследствии в ст. 11 Конституции РФ необходимо внести соответствующие уточнения о порядке заключения, выполнения, изменения и прекращения договоров о разграничении предметов ведения и перераспределении полномочий между Российской Федерацией и ее субъектами, а также установить систему взаимной правовой ответственности за ненадлежащее выполнение договорных обязательств.

\section{Constitutional and Judicial Verification of International and Interstate Agreements (Summary)}

\section{Boris A. Ossipian*}

The activity of Constitutional Court of the Russian Federation on verification of constitutionality of international agreements has great significance for optimization of the process of proper implementation of international law obligations by the Russian Government. Constitutional and judicial verification of the practice for conclusion and realization of interstate agreements enables Russia to fortify the constitutional foundations of the further development of its general and, particularly, federative development.

\section{${ }^{26}$ См.: Собрание законодательства РФ. 1998. № 3. Ст. 429.}

${ }^{27}$ См.: Овсепян Ж.И. Двусторонние договоры РФ и республик в ее составе//СевероКавказский юридический вестник. 1999. № 4.

${ }^{*}$ Boris A. Ossipian-Ph.D. in Law, associate professor, member of the International Federation and Russian Union of Journalists, special correspondent of the Russian Federation State Duma's Committee's journal "Representative Government-XXI Century". 
To verify in timely and proper manner international agreements and treaties the Constitutional Court of RF, being independent and responsible branch of State power, has to be empowered to exercise its own initiative for the verification of constitutionality thereof. Therefore, the Constitutional Court of RF has to be given an additional opportunity to control constitutionality of already acting international agreements and the process of their realization either. To put it in other words, the conclusion of the Constitutional Court of RF on constitutionality of the practice of concluding, implementing, changing and termination of international treaties must be obligatory.

In the process of verification of interstate (federative) agreements the Constitutional Court of RF is to obliged to consider the aims and requirements of Article 5 of the Constitution of Russian Federation on the right of peoples on self-determination, in particular, to guarantee the freedom of cultural development of the national subjects of the Russian Federation, and to prohibit the possibility of voluntary changing of the status and unconstitutional redistribution of there prerogatives by administrative methods. Insurance of the balance of the lawful and constitutional interests of federal and regional bodies of State power should become the main direction in activity of the Constitutional Court of the Russian Federation.

\section{ВОПРОСЫ ТЕРРИТОРИИ}

\section{Рассмотрение споров относительно островных территорий Международным судом ООН}

\section{Тимохин К.B.*}

Острова, представляющие собой особый тип территории, обладающий рядом уникальных характеристик, привлекают к себе внимание не только писателей и пиратов, но и государств и до настоящего времени продолжают являться предметом споров между ними. Достаточно вспомнить такие примеры, как споры об островах Спратли, Парасельских островах, Фолклендских островах, острове Такешима, Сенкаку. Существует также целый ряд судебных и арбитражных дел, предметом разбирательства которых являются споры об островах. Так, большинство дел, уже рассмотренных Международным судом ООН по территориальным вопросам, связаны с островными территориями, и, кроме того, в Международном суде ООН ожидается рассмотрение еще трех дел об островных территориях, расположенных в Карибском море, Океании и Черном море.

Определение понятия «остров» и значение островных территорий. В деле по спору о материковых, островных и морских границах (между Сальвадором и Гондурасом), в частности, отмечается, что территория Республики Сальвадор «включает в себя островные территории, состоящие из островов (islands), островков (isles), рифов (reefs) ${ }^{1}$ ». Кроме того, в литературе по международному праву используются такие термины, как «острова, похожие на островки» (islands similar to "Тимохин Константин Валентинович - аспирант кафедры международного права, Дипломатическая академия МИД России.

${ }^{1}$ Land, Island and Maritime Frontier Dispute (El Salvador/Honduras, Nicaragua intervening) of September 11, 1992, para. 330. I.C.J. Reports 1992. P. 557. 